\title{
Postsynaptic Expression of a New Calcium Pathway in Hippocampal CA3 Neurons and Its Influence on Mossy Fiber Long-Term Potentiation
}

\author{
Wataru Kakegawa, ${ }^{1}$ Nobuaki Yamada,, ${ }^{1,2}$ Masae lino,, ${ }^{1}$ Kimihiko Kameyama, ${ }^{3}$ Tatsuya Umeda, ${ }^{4}$ \\ Keisuke Tsuzuki, ${ }^{1}$ and Seiji Ozawa ${ }^{1,2}$ \\ 1Department of Physiology, Gunma University School of Medicine, Maebashi, Gunma 371-8511, Japan, ${ }^{2}$ Core Research \\ for Evolutional Science and Technology, Japan Science and Technology Corporation, Kawaguchi, Saitama \\ 332-0012, Japan, ${ }^{3}$ Molecular Neurophysiology Group, Neuroscience Research Institute, National Institute of Advanced \\ Industrial Science and Technology, Tsukuba, Ibaraki 305-8566, Japan, and ${ }^{4}$ Department of Anatomy and Cell Biology, \\ School of Medicine, Tokyo Medical and Dental University, Bunkyo-ku, Tokyo 113-8519, Japan
}

Long-term potentiation (LTP) in the CA1 region of the hippocampus is induced by postsynaptic $\mathrm{Ca}^{2+}$ influx via NMDA receptors (NMDARs). However, this synaptic plasticity occurs independently of NMDARs when $\mathrm{Ca}^{2+}$-permeable AMPA receptors (AMPARs) are expressed at postsynaptic sites using various genetic techniques, indicating that an increase in $\mathrm{Ca}^{2+}$ level at critical postsynaptic sites, regardless of its entry pathway, triggers the induction of LTP at CA1 synapses. In contrast, NMDARs are sparsely distributed on mossy fiber (MF) synapses in CA3 hippocampal neurons, and most evidence favors the presynaptic mechanism for LTP induction, although some reports suggested a postsynaptic mechanism. In this study, we examined whether $\mathrm{Ca}^{2+}$ influx through the newly produced postsynaptic receptors during high-frequency stimulation affects the induction of MF LTP. For this purpose, we expressed $\mathrm{Ca}^{2+}$-permeable AMPARs in CA3 pyramidal neurons by Sindbis viral-mediated gene transfer of the unedited form of the

Long-term potentiation (LTP) at hippocampal synapses provides a cellular basis for learning and memory (Bliss and Collingridge, 1993). LTP at the CA1 synapses of the hippocampus is induced by $\mathrm{Ca}^{2+}$ entry through postsynaptic NMDA receptors (NMDARs) (Chittajallu et al., 1998; Nicoll and Malenka, 1999; Malinow et al., 2000). However, it is also induced without activation of NMDARs in mutant mice either lacking the GluR2 subunit or deficient in $\mathrm{Q} / \mathrm{R}$ site editing in the GluR2 subunit that express $\mathrm{Ca}^{2+}$-permeable AMPA receptors (AMPARs) in principal neurons in the CNS, including CA1 hippocampal pyramidal cells (Jia et al., 1996; Feldmeyer et al., 1999). We showed that LTP at CA1 synapses is induced in the presence of NMDAR antagonists when $\mathrm{Ca}^{2+}$-permeable AMPARs are expressed at postsynaptic sites in CA1 pyramidal cells in rat hippocampal slice cultures by Sindbis viral-mediated gene transfer of the unedited form of glutamate receptor 2 (GluR2Q), in which an arginine (R) in the $\mathrm{Q} / \mathrm{R}$ site of the edited GluR2 was replaced with glutamine (Q) (Okada et al., 2001). These results indicated that an increase in

\footnotetext{
Received Feb. 20, 2002; revised March 19, 2002; accepted March 22, 2002.

This work was supported by Japan Science and Technology Corporation.

Correspondence should be addressed to Wataru Kakegawa, Department of Physiology, Gunma University School of Medicine, 3-39-22 Showa-machi, Maebashi, Gunma 371-8511, Japan. E-mail: wkake@med.gunma-u.ac.jp.

Copyright (C) 2002 Society for Neuroscience $0270-6474 / 02 / 224312-09 \$ 15.00 / 0$
}

glutamate receptor 2 (GluR2Q) subunit, as a new pathway for postsynaptic $\mathrm{Ca}^{2+}$ entry, in rat hippocampal organotypic cultures. Virally expressed myc-tagged GluR2Q was detected at the complex spines known as the thorny excrescences, which serve as postsynaptic targets for MF synaptic input, on the proximal apical dendrites of CA3 pyramidal cells. Furthermore, endogenous $\mathrm{Ca}^{2+}$-impermeable AMPARs at MF synapses were converted into $\mathrm{Ca}^{2+}$-permeable receptors by GluR2Q expression. However, the postsynaptic expression of $\mathrm{Ca}^{2+}$ permeable AMPARs had no significant influence on the two types of MF LTP induced by different stimulus protocols. These results supported the notion that MF LTP is independent of postsynaptic $\mathrm{Ca}^{2+}$.

Key words: mossy fiber LTP; $\mathrm{Ca}^{2+}$-permeable AMPA receptors; GluR2; $\mathrm{Ca}^{2+}$ influx; Sindbis viral vector; high-frequency stimulation; CA3; hippocampus
$\mathrm{Ca}^{2+}$ level at critical postsynaptic sites is sufficient for the induction of LTP at CA1 synapses, regardless of the pathway of $\mathrm{Ca}^{2+}$ entry.

In contrast to CA1 synapses, NMDARs are sparsely distributed on mossy fiber (MF) synapses in CA3 hippocampal neurons. Several reports have suggested that postsynaptic increases in $\mathrm{Ca}^{2+}$ level originating from voltage-dependent $\mathrm{Ca}^{2+}$ channels (VDCCs) and/or internal $\mathrm{Ca}^{2+}$ stores are involved in the induction of MF LTP (Jaffe and Johnston, 1990; Kapur et al., 1998; Yeckel et al., 1999). However, most evidence favors the notion that MF LTP is induced entirely by the presynaptic mechanism (Zalutsky and Nicoll, 1990; Ito and Sugiyama, 1991; Katsuki et al., 1991; Castillo et al., 1994; Mellor and Nicoll, 2001). The mechanism engaged by the rise in postsynaptic $\mathrm{Ca}^{2+}$ at CA1 synapses could be missing at MF synapses. This lack of involvement of the postsynaptic mechanism could be attributable to the lack of supply of $\mathrm{Ca}^{2+}$ to the critical postsynaptic sites relevant to the initiation of LTP. Alternatively, the mechanism responsible for induction of the long-lasting increase in the postsynaptic sensitivity that responds to a $\mathrm{Ca}^{2+}$ rise could be missing. To address this issue, we expressed a new $\mathrm{Ca}^{2+}$ pathway, i.e., $\mathrm{Ca}^{2+}$ permeable AMPARs, at the postsynaptic sites in CA3 pyramidal cells in hippocampal slice cultures using Sindbis viral vector- 
mediated gene transfer of GluR2Q and examined whether it had an influence on MF LTP.

\section{MATERIALS AND METHODS}

Construction of Sindbis viral vector. The recombinant Sindbis virus containing RNAs of both enhanced green fluorescent protein (GFP) and GluR2Q (GluR2Q flip) (designated as SIN-EG-GluR2Q) for expression of the GluR2Q subunit together with GFP was constructed as described previously (Okada et al., 2001). As a control, the recombinant virus encoding both the GFP gene and LacZ, designated as SIN-EG-LacZ, was also constructed. The plasmid pSinEGdsp used to construct these viruses was a generous gift from Drs. H. Nawa and M. Kawamura (Niigata University, Niigata, Japan). To trace both surface and intracellular expression of the desired protein visually, we produced the recombinant virus for expression of c-myc- and GFP-tagged GluR2Q fusion protein designated as SIN-myc-EG-GluR2Q, as described below: cDNAs of myc tag (EQKLISEEDL) and enhanced GFP were both inserted between the fifth and sixth amino acid codons after the signal peptide of the GluR2Q cDNA, and then this cDNA was ligated into the multiple cloning site of pSinRep5 (Invitrogen, Carlsbad, CA) immediately downstream of the subgenomic promoter. This product was named pSinRep5/ myc-EG-GluR2Q. Then, the recombinant RNA was transcribed from the linearized pSinRep5/myc-EG-GluR2Q with an InvitroScript CAP SP6 in vitro transcript kit (Invitrogen). The recombinant RNA was cotransfected with helper RNA into baby hamster kidney cells (BHK-21), and the produced virion was harvested as described previously (Okada et al., 2001).

Hippocampal culture. Hippocampal neurons in dissociated cultures $\left(125-200\right.$ cells $\left./ \mathrm{mm}^{2}\right)$ were prepared from day 18 rat fetuses as described previously (Brewer et al., 1993). The dissociated neurons derived from the area including the CA3 region and the dentate gyrus of the hippocampus were plated onto coverslips coated with poly-L-lysine and cultured in Neurobasal medium (Invitrogen) containing 2\% B-27 supplement (Invitrogen), $0.5 \mathrm{~mm}$ L-glutamine and $25 \mu \mathrm{M}$ glutamate in a humidified atmosphere of $5 \% \mathrm{CO}_{2}$ in air at $37^{\circ} \mathrm{C}$. One-half of the medium without glutamate was exchanged weekly thereafter.

Organotypic slice cultures of the hippocampus were prepared as reported by Stoppini et al. (1991). Briefly, the brains were removed from postnatal 9- or 10-d-old Wistar rats, and hippocampal slices at 250-350 $\mu \mathrm{m}$ thickness were cut transversely using a McIlwain tissue chopper (Mickle Laboratory Engineering, Surrey, UK) and separated with Hibernate A solution (Invitrogen). The slices were then transferred onto Millicell-CM membranes (Millipore, Bedford, MA) and cultured at $32^{\circ} \mathrm{C}$ in a humidified atmosphere of $95 \%$ air and $5 \% \mathrm{CO}_{2}$ in the medium. The slices were cultured for $10-15 \mathrm{~d}$ before use. All experiments were performed according to the guidelines of the Animal Care and Experimentation Committee of Gunma University.

Infection with recombinant Sindbis viruses. For expression of GluR2Q in cultured slices, SIN-EG-GluR2Q $\left(0.5-1.0 \times 10^{9}\right.$ infectious particles per $\mathrm{ml}$ ) was injected into several points in the stratum pyramidale in the CA3 region. For dissociated neurons in primary cultures, $3 \mu \mathrm{l}$ of the virus solution was added to the medium. To examine GluR2Q expression on the surface membrane, SIN-myc-EG-GluR2Q $\left(0.2-1.0 \times 10^{8}\right.$ infectious particles per $\mathrm{ml}$ ) was used instead of SIN-EG-GluR2Q. For control experiments to check cytotoxic effects of Sindbis viral vectors, SIN-EGLacZ $\left(0.5-1.0 \times 10^{8}\right.$ infectious particles per $\left.\mathrm{ml}\right)$ was used. Experiments with dissociated cultured neurons and slices were performed at 24 and $36-48 \mathrm{hr}$ after infection, respectively.

Immunohistochemistry. To examine the expression of the desired protein on the surface membrane, we added monoclonal anti-myc antibody (Santa Cruz Biotechnology, Santa Cruz, CA) directly to the culture medium at a concentration of $10 \mu \mathrm{g} / \mathrm{ml}$ and incubated the cells for $20 \mathrm{~min}$ at $37^{\circ} \mathrm{C}$. For slice cultures, Millicell-CM membranes were cut, and then the tissues were soaked in culture medium during immunoreaction $(\sim 30$ min). Dissociated cells or cultured slices were washed with prewarmed medium three times and then reacted with Alexa594-conjugated antimouse secondary antibody (1:500; Molecular Probes, Eugene, OR) at $37^{\circ} \mathrm{C}$. They were rinsed in PBS and fixed with $4 \%$ paraformaldehyde in PBS at room temperature. Subsequently, to confirm the exogenous GluR2Q expression on the postsynaptic membranes, samples were reacted with polyclonal anti-synaptophysin antibody (1:100; PharMingen, San Diego, CA) for $1 \mathrm{hr}$ at room temperature after permeabilization with $0.1 \%$ Triton X-100 and subsequent incubation in $10 \%$ normal goat serum in PBS to block nonspecific binding. Cy5-labeled secondary antibody (1:1000, goat anti-rabbit IgG; Amersham Biosciences, Piscataway, NJ) was used to visualize the bound antibodies. The stained cells were viewed with a confocal laser-scanning microscope (MRC1024; Bio-Rad, Cambridge, MA).

Electrophysiology. Whole-cell recordings from CA3 pyramidal cells were performed using an EPC-8 patch-clamp amplifier (Heka, Lambrecht, Germany), and the pClamp system (version 7; Axon Instruments, Foster City, CA) was used for data acquisition and analysis. The current traces were filtered at $1 \mathrm{kHz}$ and digitized at $2 \mathrm{kHz}$ for AMPA-induced currents or $10 \mathrm{kHz}$ for EPSCs). Patch pipettes had a resistance of 3-5 $\mathrm{M} \Omega$ when filled with internal solution, and the series resistance during recording was typically 10-20 M 2 . Pipette solutions contained (in mM): $150 \mathrm{Cs}$ gluconate, $8 \mathrm{NaCl}, 2 \mathrm{MgATP}, 10 \mathrm{HEPES}, 0.2$ EGTA, $5 \mathrm{~N}$-ethyl bromide quaternary salt (QX-314), and 0.1 spermine, adjusted to $\mathrm{pH} 7.2$ with gluconic acid. QX-314 was added to the internal solution to block voltage-dependent $\mathrm{Na}^{+}$currents (Stuart and Sakmann, 1994), and spermine was added to maintain the inwardly rectifying properties of the $\mathrm{Ca}^{2+}$-permeable AMPARs (Isa et al., 1995). The actual membrane potential was corrected by the liquid junction potential of $-10 \mathrm{mV}$ between the pipette solution and the control external solution. The slices were transferred into a recording chamber on the stage of an infrared differential interference contrast upright microscope (Leica DM LFS; Leica, Wetzlar, Germany) and held down with a U-shaped platinum wire with several fine nylon threads (fastened at $1.5 \mathrm{~mm}$ intervals) (Edwards et al., 1989). The slice was superfused continuously with the control external solution composed of (in $\mathrm{mM}$ ): $125 \mathrm{NaCl}, 2.5 \mathrm{KCl}, 2 \mathrm{CaCl}_{2}, 1$ $\mathrm{MgCl}_{2}, 26 \mathrm{NaHCO}_{3}, 1.25 \mathrm{NaH}_{2} \mathrm{PO}_{4}$ and 10 D-glucose (bubbled with $95 \%$ $\mathrm{O}_{2}$ and $5 \% \quad \mathrm{CO}_{2}$ at $32^{\circ} \mathrm{C}$ ). To evoke AMPAR-mediated responses, AMPA was applied iontophoretically to the proximal portion of the apical dendrites of CA3 pyramidal cells using high-resistance (100-200 $\mathrm{M} \Omega$ ) electrodes filled with $100 \mathrm{mM}$ AMPA. AMPA was applied with 5-10 msec current pulses of 500-1000 nA. For recording, $10 \mu \mathrm{M} \mathrm{cy-}$ clothiazide (CTZ) was added to the external solution to reduce desensitization (Yamada and Tang, 1993). For experiments to measure $\mathrm{Ca}^{2+}$ permeability of AMPARs, the high $\mathrm{Ca}^{2+}$ external solution with the following composition was used (in mM): $140 \mathrm{~N}$-methyl-D-glucamine, 10 $\mathrm{CaCl}_{2}, 10$ D-glucose, and 10 HEPES, adjusted to pH 7.4 with $\mathrm{HCl}$. EPSCs were recorded by electrical stimulation (duration, 100-200 $\mu \mathrm{sec}$ ) of MFs in the CA3 region using a tungsten concentric bipolar electrode (Unique Medical, Tokyo, Japan). We continuously applied two different NMDAR antagonists, i.e., the competitive antagonist, D-2-amino-5phosphonovalerate (D-APV) $(25 \mu \mathrm{M})$ and the NMDAR open-channel blocker (+)-5-methyl-10,11-dihydro-5H-dibenzo [a,d] cyclohepten-5,10imine maleate (MK-801) $(20 \mu \mathrm{M})$, to abolish EPSCs mediated by NMDAR. The application of these antagonists abolished completely the NMDA component of EPSCs at CA1 synapses in organotypic hippocampal slices. Furthermore, EPSCs at MF synapses were unaffected by the application of these drugs, indicating that the NMDA component is lacking in MF EPSCs. We also applied $100 \mu \mathrm{M}$ picrotoxin to block $\mathrm{GABA}_{\mathrm{A}}$-mediated currents and $5 \mu \mathrm{M}$ 2-chloroadenosine to remove polysynaptic postsynaptic currents (Hayashi et al., 2000).

In LTP experiments, the stimulating electrodes were placed in the stratum lucidum at a lateral distance of $200-400 \mu \mathrm{m}$ from the patch pipette for recording MF EPSCs from CA3 neurons. Test stimuli were applied at a rate of $0.1 \mathrm{~Hz}$, and two different patterns of high-frequency stimulation (HFS) were administered to induce LTP (see Results). Whole-cell currents were recorded at the holding potential of $-60 \mathrm{mV}$. The stimulus intensity was adjusted to elicit a response of $\sim 30 \%$ of a maximal response. Series and input resistances were monitored every 10 sec by measuring the peak and steady-state currents in response to $2 \mathrm{mV}$, $50 \mathrm{msec}$ hyperpolarizing steps. The magnitude of LTP was estimated by dividing the average amplitude of 30 responses evoked 25-30 min after the HFS by the average amplitude of responses evoked in the $5 \mathrm{~min}$ before delivery of the HFS. At the end of each LTP session, the rectification index (RI) value (see Results) was estimated to quantify the degree of inward rectification of current responses of AMPARs, and then $\left(2 S, 1^{\prime} S, 2^{\prime} S\right)$-2-(carboxycyclopropyl)-glycine (L-CCG-I) $(20 \mu \mathrm{M})$, a group II metabotropic glutamate receptor (mGluR) agonist, was applied to check the selective stimulation of MFs.

All data are expressed as means \pm SEM. Statistical analysis was performed using the Mann-Whitney $U$ test.

Materials. cDNA of the GluR2 flip subunit was kindly provided by Drs. Stephan F. Heinemann and Michael Hollmann (Salk Institute, La Jolla, CA). AMPA, D-APV, CTZ, and L-CCG-I were purchased from Tocris Cookson (Bristol, UK). QX-314 was from Research Biochemicals (Natick, MA). Picrotoxin was from Wako (Osaka, Japan). Spermine and 

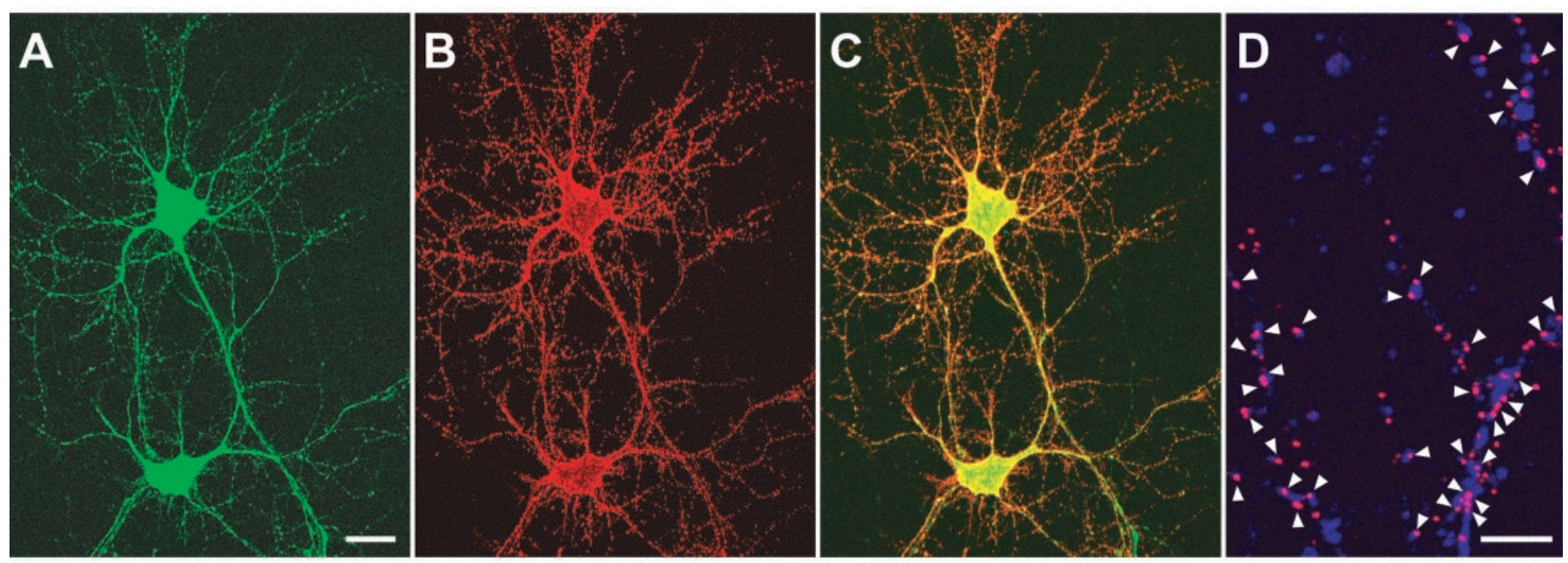

Figure 1. Sindbis viral-mediated expression of GluR2Q in hippocampal neurons in monolayer culture. Dissociated neurons derived from the area including the CA3 region and the dentate gyrus of the rat hippocampus were infected with SIN-myc-EG-GluR2Q for expression of the myc-GFP-tagged GluR2Q fusion protein $18 \mathrm{hr}$ before examination. $A$, Infected neurons emitting GFP fluorescence. $B$, Cell-surface expression of myc-GFP-tagged GluR2Q fusion protein. Cell-surface staining was performed using anti-myc antibody and Alexa594-conjugated secondary antibody (red). $C$, A merged image of $A$ and $B . D$, Colocalization of myc-tagged GluR2Q (red) and synaptophysin (purple) immunoreactivity. After staining for cell-surface expression of myc-GFP-tagged GluR2Q, cells were permeabilized and then treated with anti-synaptophysin antibody and Cy5-conjugated secondary antibody. Arrowheads indicate colocalization. Scale bars: $A-C, 20 \mu \mathrm{m} ; D, 5 \mu \mathrm{m}$.

MK-801 were from Sigma (St. Louis, MO), and 2-chloroadenosine was from ICN Biomedicals (Aurora, OH).

\section{RESULTS}

\section{Sindbis viral-mediated expression of myc-tagged GluR2Q in dissociated hippocampal neurons}

We first examined Sindbis viral-mediated expression of the GluR2Q subunit in pyramidal cell-like neurons in dissociated cultures derived from the area including the CA3 region and the dentate gyrus of the hippocampus. We infected cultured neurons with SIN-myc-EG-GluR2Q for expression of myc-GFP-GluR2Q fusion protein and performed immunohistochemical staining using myc-specific antibody $24 \mathrm{hr}$ after infection in pyramidal celllike neurons. GFP fluorescence from neurons infected with SINmyc-EG-GluR2Q was observed as early as $6 \mathrm{hr}$, and one-half of the neurons emitted readily detectable levels of GFP fluorescence that were diffusely observed throughout the soma and dendrites at $24 \mathrm{hr}$ after infection (Fig. 1A). To detect the expression of GluR2Q on the surface membrane, we performed immunohistochemical staining with anti-myc antibody under nonpermeabilizing conditions. A large number of myc-positive spots were detected on the surface membrane of the soma and dendrites of neurons emitting green fluorescence (Fig. $1 B, C$ ). We next examined the expression of the fusion protein on the postsynaptic sites using anti-synaptophysin antibody. The majority of myc-positive spots were detected in apposition to the presynaptic structures detected by anti-synaptophysin immunoreactivity (Fig. $1 D$ ), indicating that a substantial amount of myc-tagged GluR2Q is targeted to synapses and expressed on the postsynaptic membrane.

\section{Functional expression of GluR2Q in CA3 pyramidal cells in cultured hippocampal slices}

We next infected cultured hippocampal slices with SIN-EGGluR2Q for expression of both GFP and GluR2Q separately in the same neurons and assessed functional expression of $\mathrm{Ca}^{2+}$ permeable AMPARs. Figure $2 \mathrm{Aa}$ shows the CA3 region at $48 \mathrm{hr}$ after infection. Sindbis viral-mediated GFP expression was detected in neurons (predominantly from pyramidal cells) but not in glial cells, as reported previously (Gwag et al., 1998; Ehrengruber et al., 1999). In an infected CA3 pyramidal cell, the green fluorescence was observed diffusely throughout the soma and dendrites (Fig. 2Ab). We recorded current responses to the iontophoretic application of AMPA to the proximal portion of the apical dendrite of infected cells using the whole-cell patch-clamp technique. In uninfected cells, the current-voltage $(I-V)$ relationship was either linear or showed slight inward or outward rectification in the control external solution (Fig. $2 B$ ). The permeability to $\mathrm{Ca}^{2+}$ of AMPARs was examined by substituting $\mathrm{Na}^{+}$-free, $10 \mathrm{mM} \mathrm{Ca}^{2+}$ solution for control saline. No inward current response to AMPA was detected, even at $-80 \mathrm{mV}$ in $\mathrm{Na}^{+}$-free, $10 \mathrm{mM} \mathrm{Ca}^{2+}$ solution, indicating virtually no $\mathrm{Ca}^{2+}$ permeability in AMPARs in uninfected cells. The permeability of $\mathrm{Ca}^{2+}$ relative to that of $\mathrm{Cs}^{+}\left(P_{\mathrm{Ca}} / P_{\mathrm{Cs}}\right)$ was $<0.17$ according to the constant field equation (Hodgkin and Katz, 1949; Iino et al., 1990). On the other hand, the AMPARs showed strong inward rectification in some CA3 pyramidal cells expressing GFP at 36-48 hr after infection with SIN-EG-GluR2Q. In these cells, the AMPAinduced current reversed at approximately $-25 \mathrm{mV}$ in $\mathrm{Na}^{+}$-free, $10 \mathrm{~mm} \mathrm{Ca}^{2+}$ solution, indicating high $\mathrm{Ca}^{2+}$ permeability $\left(P_{\mathrm{Ca}}\right)$ $P_{\mathrm{Cs}} \approx 2.0$ ) (Fig. 2C) (Iino et al., 1990; Burnashev et al., 1992). In most SIN-EG-GluR2Q-infected pyramidal neurons, however, the degrees of both inward rectification and $\mathrm{Ca}^{2+}$ permeability of AMPARs were less prominent than those shown in Figure $2 C$. To evaluate the efficiency of functional expression of the transferred gene more quantitatively, we introduced the RI, defined as the conductance of the AMPA response measured at $+40 \mathrm{mV}$ divided by the conductance at $-60 \mathrm{mV}$ (Ozawa et al., 1991; Isa et al., 1996). Figure $2 D$ shows scatter plots between the RIs of AMPA responses in the control solution and the reversal potential values of AMPA responses in $\mathrm{Na}^{+}$-free, $10 \mathrm{mM} \mathrm{Ca}^{2+}$ solution recorded from SIN-EG-GluR2Q-infected cells. As controls, the data obtained from uninfected cells and SIN-EG-LacZ-infected cells (to check the cytotoxicity of Sindbis viral vectors) were also plotted. The RI values ranged from 0.24 to 0.85 in SIN-EGGluR2Q-infected cells $(0.589 \pm 0.043 ; n=20)$. In contrast, the 

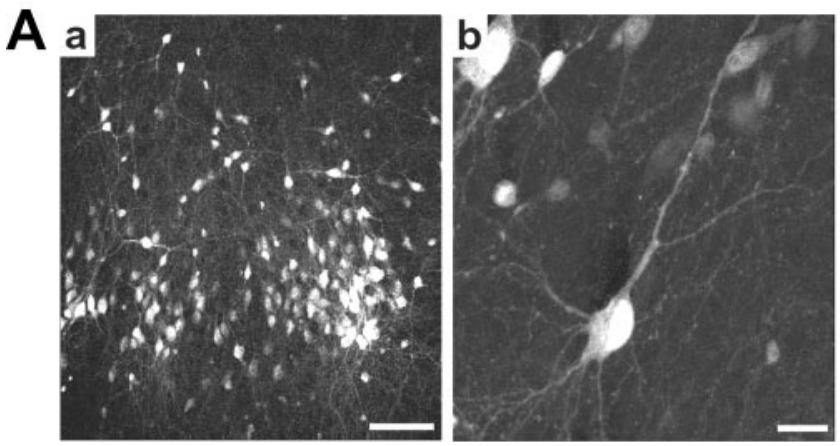

\section{SIN-EG-GluR2Q}

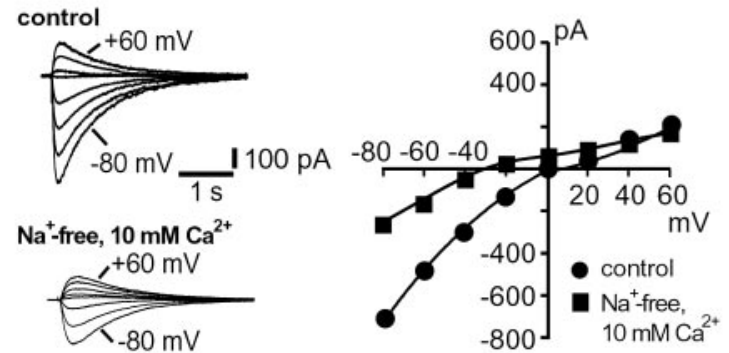

\section{B Uninfected}

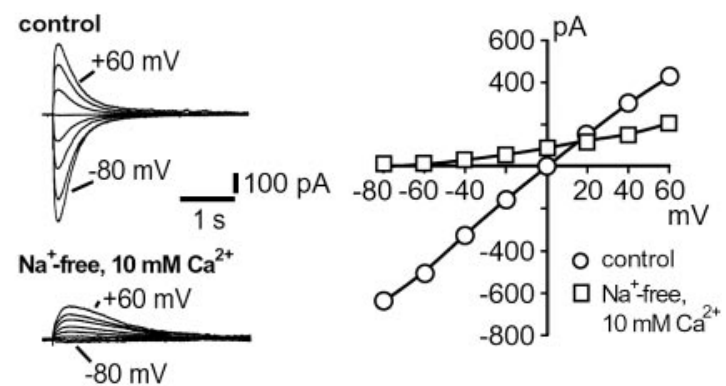

D

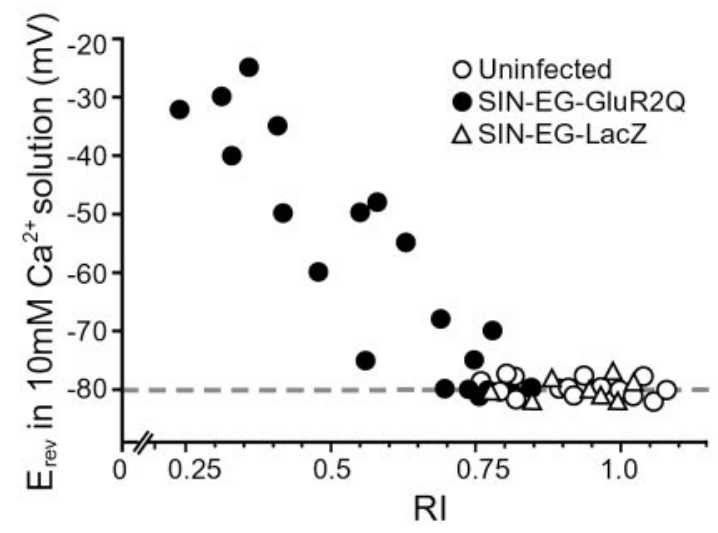

Figure 2. Changes in properties of AMPARs caused by GluR2Q expression in CA3 pyramidal neurons in cultured hippocampal slices. $A$, Hippocampal CA3 region $(a)$ and an isolated single CA3 pyramidal neuron $(b)$ infected with SIN-EG-GluR2Q. Scale bars: $a, 100 \mu \mathrm{m} ; b, 20 \mu \mathrm{m} . B, C$, Current responses to AMPA recorded from uninfected $(B)$ and SIN-EG-GluR2Q-infected $(C)$ cells. AMPA was applied iontophoretically to the proximal portion of the apical dendrites of CA3 pyramidal cells in the stratum lucidum, and current responses were recorded at various membrane potentials between -80 and $+60 \mathrm{mV}$ in $20 \mathrm{mV}$ steps in both control (left top) and $\mathrm{Na}^{+}$-free, $10 \mathrm{mM} \mathrm{Ca}^{2+}$ solutions (left bottom) in the presence of $10 \mu \mathrm{M} \mathrm{CTZ}$. The peak amplitude of each response was plotted against the holding potential (circles, control solution; squares, $\mathrm{Na}^{+}$-free, $10 \mathrm{~mm} \mathrm{Ca}{ }^{2+}$ solution). $D$, Scatter plots of reversal potentials $\left(E_{\text {rev }}\right)$ of AMPA responses in $\mathrm{Na}^{+}$-free, $10 \mathrm{mM} \mathrm{Ca}^{2+}$ solution against RI values in the control external solution. The filled circles indicate the data obtained from SIN-EG-GluR2Q-infected cells $(n=20)$. As controls, data were also obtained from 15 uninfected cells $($ open circles) and eight cells infected with SIN-EG-LacZ (open triangles).

values in uninfected cells ranged from 0.76 to $1.08(0.924 \pm 0.027$; $n=15)$ and those in SIN-EG-LacZ-infected cells from 0.78 to $1.02(0.931 \pm 0.030 ; n=8)$. The values in SIN-EG-GluR2Qinfected cells were significantly lower than those in uninfected or SIN-EG-LacZ-infected cells ( $p<0.0001$ in both comparisons). The reversal potential of AMPA-induced currents in SIN-EGGluR2Q-infected cells in $\mathrm{Na}^{+}$-free, $10 \mathrm{mM} \mathrm{Ca}^{2+}$ solution also varied widely, ranging from $-25 \mathrm{mV}$ to potentials more negative than $-80 \mathrm{mV}$, indicating that $P_{\mathrm{Ca}} / P_{\mathrm{Cs}}$ ranged from 2.0 and $<0.17$. There was a close correlation between the degree of inward rectification and the $\mathrm{Ca}^{2+}$ permeability of AMPARs in SIN-EGGluR2Q-infected cells, as shown in the scatter plots in Figure 2D. In both uninfected cells and SIN-EG-LacZ-infected cells, the reversal potential of the AMPA response in $\mathrm{Na}^{+}$-free, $10 \mathrm{~mm}$ $\mathrm{Ca}^{2+}$ solution was invariably more negative than $-80 \mathrm{mV}$. These results indicated that GluR2Q delivered by Sindbis viral vectors are expressed functionally and conferred $\mathrm{Ca}^{2+}$ permeability on the AMPARs in CA3 pyramidal cells.

\section{Expression of GluR2Q at MF synapses}

To assess the expression of newly produced GluR2Q at postsynaptic sites of MF synapses, we performed immunohistochemical staining with anti-myc antibody under nonpermeabilizing conditions in CA3 pyramidal cells in cultured slices infected with SIN-myc-EG-GluR2Q. The surface expression of myc was detected in almost all pyramidal cells emitting green fluorescence, and a large number of myc-positive spots were found on a par-
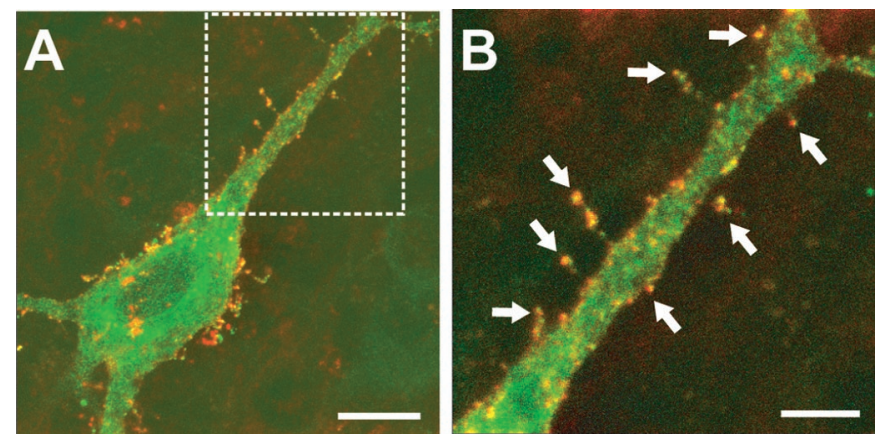

Figure 3. Expression of myc-GFP-tagged GluR2Q on dendritic spines of a CA3 pyramidal cell. $A$, Localization of myc-tagged GluR2Q on the surface membrane of a single infected neuron emitting GFP fluorescence in a cultured hippocampal slice infected with SIN-myc-EG-GluR2Q. Green, GFP fluorescence; orange, myc-GFP-tagged GluR2Q detected by cell-surface staining with anti-myc antibody. $B$, Higher magnification of the boxed area in $A$. Myc-positive spots were seen on the specialized dendritic spines, thorny excrescences (arrows). Scale bars: $A, 10 \mu \mathrm{m} ; B, 5 \mu \mathrm{m}$.

ticular type of dendritic spines, termed thorny excrescences, on the proximal dendrites of CA3 pyramidal neurons (Fig. $3 A, B$ ) (Blackstad and Kjaerheim, 1961; Amaral and Dent, 1981; Chicurel and Harris, 1992). Because these thorns serve as postsynaptic targets for the MF inputs, the localization of myc-positive spots on the complex spines suggested that GluR2Q expressed by 

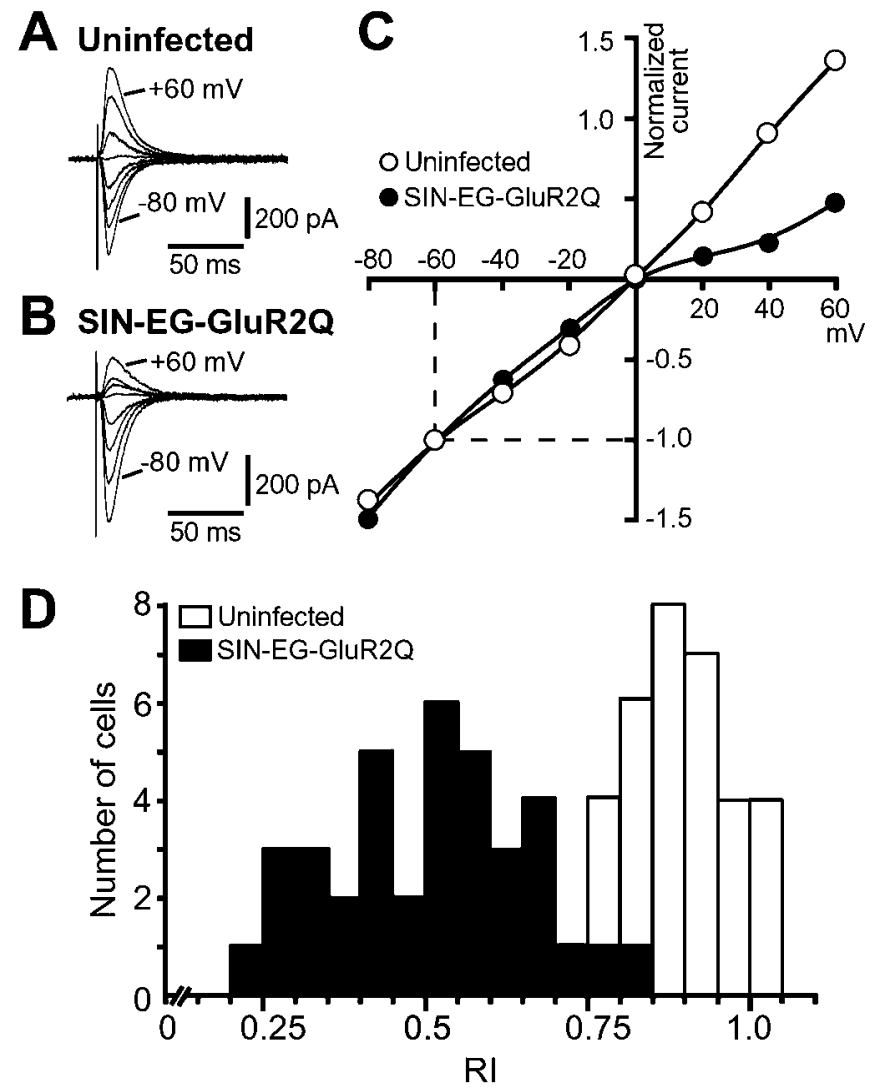

Figure 4. Changes in properties of AMPA EPSCs caused by GluR2Q expression at hippocampal MF synapses. $A, B$, Representative AMPA EPSCs evoked by stimulation of MFs in uninfected $(A)$ and SIN-EGGluR2Q-infected $(B)$ CA3 pyramidal cells. The EPSCs were recorded at various membrane potentials between -80 and $+60 \mathrm{mV}$ in $20 \mathrm{mV}$ steps in the presence of $25 \mu \mathrm{M}$ D-APV and $20 \mu \mathrm{M}$ MK- 801 . To reduce polysynaptic excitation, $5 \mu \mathrm{M}$ 2-chloroadenosine was also applied to the external solution. $C, I-V$ relationship of AMPA EPSCs shown in $A$ and $B$. The amplitudes of EPSCs normalized to those at $-60 \mathrm{mV}$ were plotted against the holding potential. The open and filled circles indicate the data from uninfected cells and those infected with SIN-EG-GluR2Q, respectively. $D$, Histogram showing the distribution of RI values of AMPA EPSCs in SIN-EG-GluR2Q-infected cells ( filled bars; $n=37$ ) and uninfected cells (open bars; $n=31$ ).

the Sindbis virus was effectively targeted to the postsynaptic sites at MF synapses.

We then examined whether GluR2Q targeted to the thorny excrescences contributed to excitatory transmission at MF synapses by recording EPSCs evoked by stimulation of MFs from CA3 pyramidal cells. In uninfected cells, the $I-V$ relationship of the peak amplitude of the AMPA component of MF EPSC (AMPA EPSC) was either linear or exhibited a slight inward or outward rectification in the control solution (Fig. 4A, C, open circles). The RI value of the AMPA EPSC ranged from 0.78 to $1.04(0.898 \pm 0.013 ; n=31)$ (Fig. $4 D)$. On the other hand, the AMPA EPSC showed inward rectification in SIN-EG-GluR2Qinfected cells (Fig. 4B, C, filled circles), and the RI value ranged from 0.23 to $0.81(0.506 \pm 0.024 ; n=37)$ (Fig. $4 D)$. This RI value in SIN-EG-GluR2Q-infected cells was significantly lower than that in uninfected cells $(p<0.0001)$. The significant reduction of the RI value in the AMPA EPSC by infection with SIN-EGGluR2Q indicated that the EPSCs at MF synapses are generated at least partially by activation of GluR2Q-including AMPARs. Thus, a new pathway for $\mathrm{Ca}^{2+}$ influx into postsynaptic sites was generated at MF synapses on CA3 pyramidal neurons by Sindbis viral-mediated gene transfer of GluR2Q.

\section{Induction of MF LTP is independent of postsynaptic} $\mathrm{Ca}^{2+}$ influx via $\mathrm{Ca}^{2+}$-permeable AMPARs

To examine the influence of the newly expressed pathway for $\mathrm{Ca}^{2+}$ entry on MF LTP, we induced LTP by two different patterns of high-frequency stimulation, that is, long trains of high-frequency stimulation (L-HFS) (three bursts of 100 stimuli at $100 \mathrm{~Hz}$, given $20 \mathrm{sec}$ apart) (Zalutsky and Nicoll, 1990) and brief trains of high-frequency stimulation (B-HFS) (15 bursts of seven stimuli at $100 \mathrm{~Hz}$, repeated every $5 \mathrm{sec}$ ) (Jaffe and Johnston, 1990; Urban and Barrionuevo, 1996).

We first tested the influence of GluR2Q expression on MF LTP induced by L-HFS. MF EPSCs were recorded from CA3 pyramidal cells infected with SIN-EG-GluR2Q. To determine whether EPSCs were evoked monosynaptically by stimulation of MFs, we applied L-CCG-I, a specific agonist of group II mGluRs, at the end of each experiment. The addition of $20 \mu \mathrm{M} \mathrm{L-CCG-I}$ reduced the amplitude of the EPSC to $<10 \%$ of control, indicating that the signal was generated predominantly by MF inputs (Kamiya et al., 1996). As a control, LTP recording was performed from uninfected CA3 pyramidal cells under the same stimulus conditions. The L-HFS induced prominent LTP in both uninfected and SIN-EG-GluR2Q-infected cells (Fig. 5A,B). The mean value of the amplitude of MF EPSCs at 30 min after tetanus relative to that before tetanus was $172.5 \pm 11.2 \%(n=5)$ in SIN-EG-GluR2Q-infected cells, similar to that in uninfected cells $(173.4 \pm 9.6 \% ; n=6)$. The time course of post-tetanic potentiation (PTP) was also similar (Fig. $5 C$ ). The mean RI value of the MF EPSC reflecting the degree of contribution of $\mathrm{Ca}^{2+}$. permeable AMPARs was $0.450 \pm 0.067$ in the SIN-EG-GluR2Qinfeceted cells $(n=5)$. This value was significantly lower than the corresponding value in uninfected cells $(0.878 \pm 0.034 ; n=6 ; p<$ $0.05)$. There was no significant correlation between the magnitude of LTP and the RI value (Fig. 5D), indicating that the newly produced $\mathrm{Ca}^{2+}$ pathway at the postsynaptic membrane had no influence on MF LTP induced by L-HFS.

It has been reported that L-HFS and B-HFS induce two distinct types of MF LTP, each having different time courses and different sensitivities to intracellular dialysis during whole-cell recordings (Urban et al., 1994; Langdon et al., 1995). In particular, B-HFS has been suggested to induce a form of LTP that depends on an initial postsynaptic event (Urban and Barrionuevo, 1996). Therefore, we next examined the influence of GluR2Q expression on MF LTP induced by B-HFS. This pattern of tetanic stimulation elicited stable LTP in both uninfected and SIN-EG-GluR2Q-infected cells (Fig. 6 $A, B$ ). In both groups of cells, LTP induced by B-HFS showed a similar time course with no PTP, which was prominent in LTP induced by L-HFS (Fig. $6 C$ ), as described previously (Urban and Barrionuevo, 1996). The mean value of the amplitude of MF EPSCs at 30 min after tetanus relative to those before tetanus was $161.3 \pm 12.8 \%$ in SIN-EG-GluR2Q-infected cells (RI value of $0.416 \pm 0.070 ; n=$ $5)$. This value was similar to the corresponding value in uninfected cells (157.9 $\pm 9.6 \%$; RI value of $0.854 \pm 0.026 ; n=5)$. Furthermore, there was no significant correlation between the magnitude of LTP and the RI value (Fig. 6D). Thus, the newly produced $\mathrm{Ca}^{2+}$ pathway had no influence on the B-HFS-induced LTP, either.

The above results strongly suggested that MF LTP is independent of postsynaptic $\mathrm{Ca}^{2+}$. However, it could be argued that MF 
A Uninfected

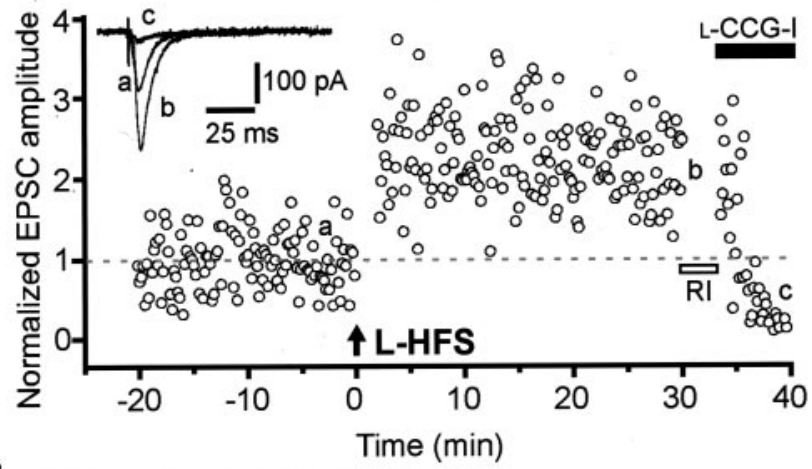

B SIN-EG-GIUR2Q
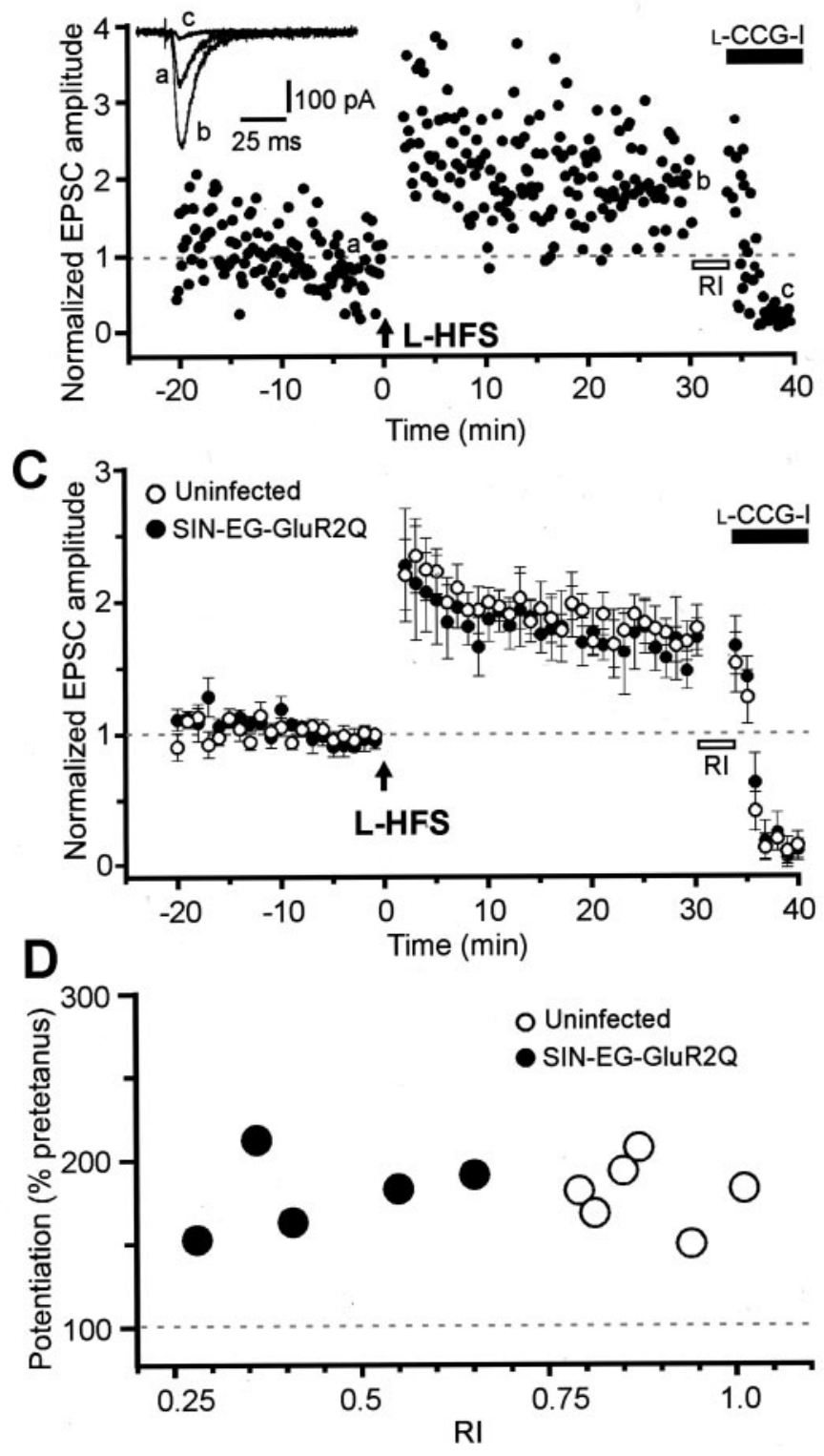

Figure 5. No effect of postsynaptic $\mathrm{Ca}^{2+}$ influx via $\mathrm{Ca}^{2+}$-permeable AMPARs on MF LTP induced by L-HFS. $A, B$, LTP in uninfected $(A)$ or SIN-EG-GluR2Q-infected $(B)$ CA3 pyramidal cells. The peak amplitudes of consecutive MF EPSCs are plotted against time (holding potential, $-60 \mathrm{mV}$ ). The test pulse was applied at a rate of $0.1 \mathrm{~Hz}$, and L-HFS (three trains of 100 pulses at $100 \mathrm{~Hz}$; intertrain interval, $20 \mathrm{sec}$ ) was given
LTP induced with either stimulation protocol would be dependent on postsynaptic $\mathrm{Ca}^{2+}$, but the stimulation used in these experiments would be strong enough to saturate the induction of MF LTP so that an additional increase in postsynaptic $\mathrm{Ca}^{2+}$ through the newly produced $\mathrm{Ca}^{2+}$ pathway would have no influence on MF LTP. To test this possibility, we used a weaker HFS stimulus protocol (one burst of 100 stimuli at $100 \mathrm{~Hz}$ ) and induced a smaller magnitude of MF LTP. Under these conditions, the mean value of the amplitude of MF EPSCs at $30 \mathrm{~min}$ after tetanus relative to those before tetanus was $127.6 \pm 5.9 \%$ in SIN-EG-GluR2Q-infected cells (RI value of $0.378 \pm 0.048 ; n=$ $5)$. This value was similar to the corresponding value in uninfected cells $(126.4 \pm 4.9 \%$; RI value of $0.831 \pm 0.028 ; n=7)$. Thus, under conditions in which the induction of MF LTP was not saturated, an increase in $\mathrm{Ca}^{2+}$ influx through the new $\mathrm{Ca}^{2+}$ pathway had no influence on the magnitude of LTP.

\section{DISCUSSION}

Morphological studies have demonstrated that mossy fiber terminals in organotypic hippocampal cultures maintain their normal complex structure and restricted distribution on CA3 pyramidal neurons (Robain et al., 1994). The morphology, location, ultrastructure of the complex spines (thorny excrescences), and the sensitivity of EPSP to the specific group II mGluR agonist in the intact brain are also maintained in organotypic slice cultures (Reid et al., 2001). In this study, we showed that $\mathrm{Ca}^{2+}$-permeable AMPARs expressed by Sindbis viral-mediated gene transfer of GluR2Q are effectively sorted into the complex spines and function as new postsynaptic receptor channels at MF synapses in organotypic hippocampal cultures. This generation of new pathways for $\mathrm{Ca}^{2+}$ entry in the complex spines, however, had no influence on the induction of MF LTP by two distinct patterns of HFS, supporting the notion that MF LTP is independent of postsynaptic $\mathrm{Ca}^{2+}$.

\section{Trafficking of newly produced GluR2Q to MF synapses}

AMPARs are hetero-oligomeric receptors composed of four subunits, GluR1-GluR4 (Seeburg, 1993; Hollmann and Heinemann, 1994). In the hippocampus, GluR4 is mainly expressed early in development, whereas in the adult hippocampus, GluR1-GluR3 subunits are dominant, and they combine to form two distinct populations of AMPARs: GluR1/GluR2 and GluR2/GluR3

at the time $(t=0 \mathrm{~min})$ indicated by the arrow. At the end of each LTP session, the RI value was estimated to quantify the degree of inward rectification of current responses of AMPARs (open bars), and then 20 $\mu \mathrm{M}$ L-CCG-I was applied to check the selective stimulation of MFs ( filled bars). Insets show representative traces of EPSCs before $(a)$ and $30 \mathrm{~min}$ after $(b)$ tetanic stimulation and the traces recorded during L-CCG-I application $(c)$. Each trace is the average of six traces for $1 \mathrm{~min}$. $C$, Summary of the data obtained from uninfected (open circles; $n=6$ ) and SIN-EG-GluR2Q-infected ( filled circles; $n=5$ ) CA3 pyramidal cells. The normalized EPSC amplitude on the ordinate represents the EPSC amplitude of the average of six traces for 1 min divided by that of the average of 30 traces for 5 min immediately before tetanic stimulation $(t=-5$ to $0 \mathrm{~min}$ ) in each cell. There was no significant difference in the magnitude of LTP between uninfected and SIN-EG-GluR2Q-infected cells. D, Scatter plots showing no correlation between the magnitude of LTP and the RI value of MF EPSCs in uninfected (open circles) and SIN-EG-GluR2Qinfected (filled circles) cells. The magnitude of LTP was estimated by dividing the amplitude of the average of 30 consecutive EPSCs between 25 and 30 min after tetanus by the corresponding amplitude between -5 and 0 min before tetanus. The RI value was estimated from the $I-V$ relationship of the EPSC at the end of each experiment. 


\section{A Uninfected}

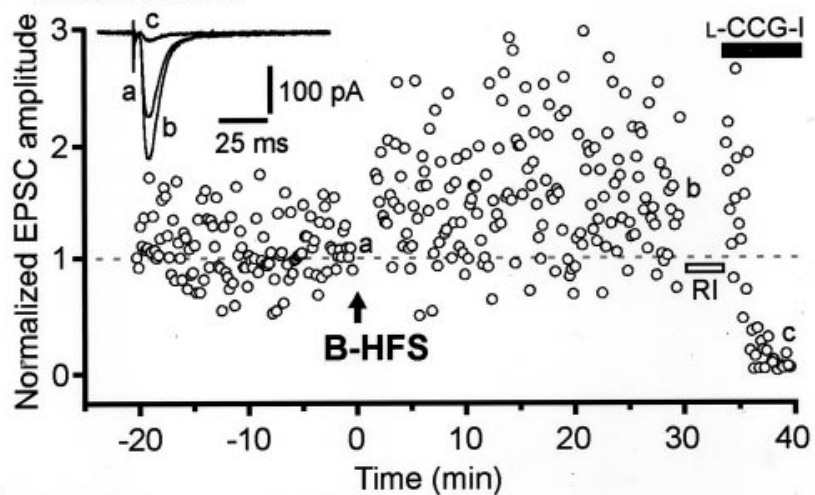

B SIN-EG-GIuR2Q
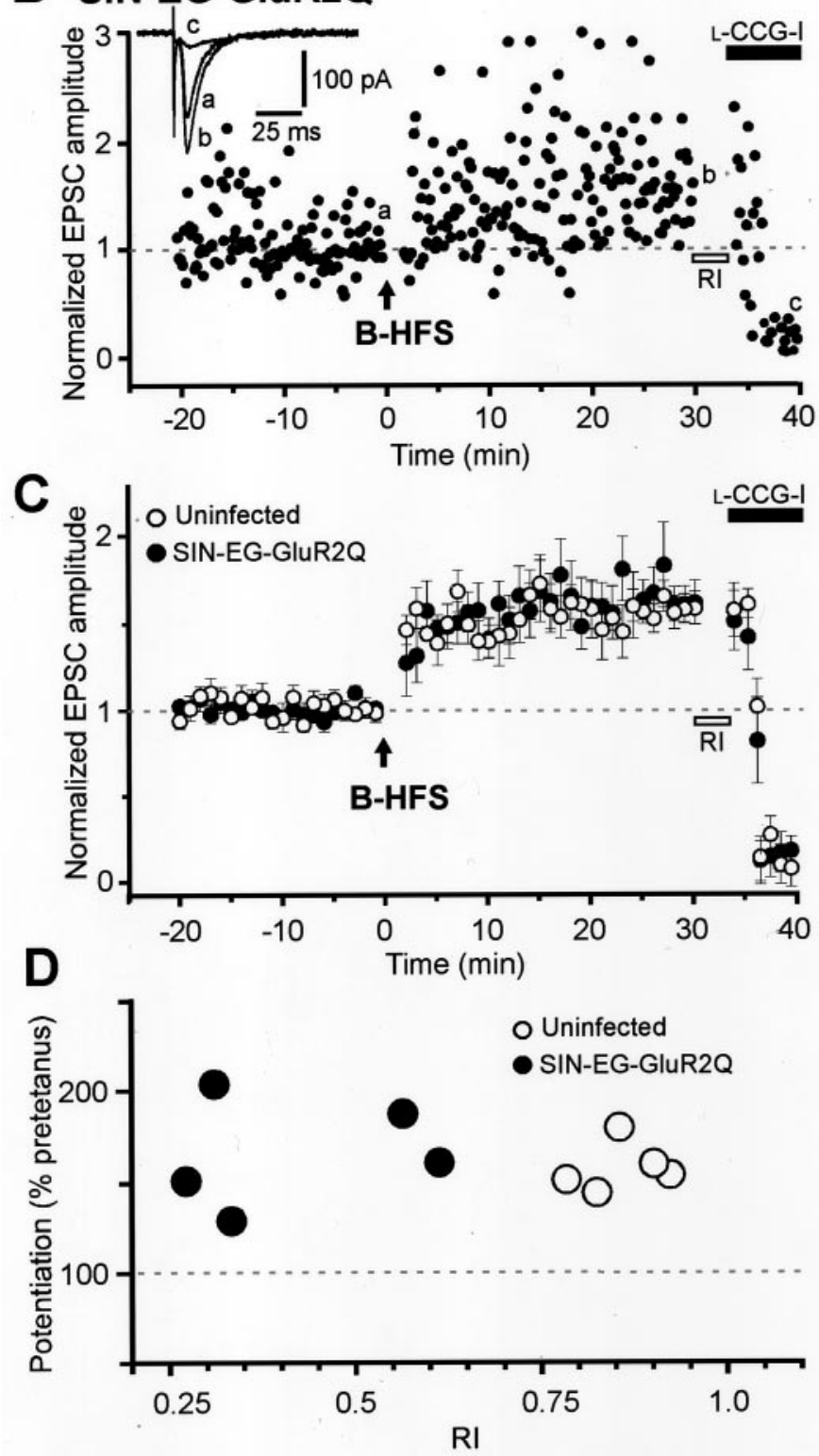

Figure 6. No effect of postsynaptic $\mathrm{Ca}^{2+}$ influx via $\mathrm{Ca}^{2+}$-permeable AMPARs on MF LTP induced by B-HFS. Experimental arrangements were identical to those in Fig. 5, except that B-HFS (15 bursts of 7 stimuli at $100 \mathrm{~Hz}$, repeated every $5 \mathrm{sec}$ ) was used, instead of L-HFS, for induction of LTP. $A, B$, LTP in uninfected $(A)$ or SIN-EG-GluR2Q-infected $(B)$ hetero-oligomers (Wenthold et al., 1996). Recently, Shi et al. (2001) showed that these AMPARs display different synaptic delivery mechanisms at hippocampal CA1 synapses in organotypic slice cultures. GluR1/GluR2 receptors are added to synapses in an activity-dependent manner during plasticity. This requires interaction between GluR1 and group I PDZ (postsynaptic density-95/Discs large/zona occludens-1) domain proteins. In contrast, GluR2/GluR3 receptors replace existing synaptic receptors continuously in an activity-independent manner, which requires interactions by GluR2 with $N$-ethylmaleimide-sensitive factor and group II PDZ domain proteins (Shi et al., 2001). It has been shown that GluR2Q is readily incorporated into hippocampal CA1 synapses to form postsynaptic $\mathrm{Ca}^{2+}$-permeable AMPARs by the Sindbis virus expression system in an activityindependent manner in organotypic hippocampal cultures (Okada et al., 2001; Shi et al., 2001). Because expression of GluR2 using this system led predominantly to the formation of homomeric recombinant receptors, it was suggested that newly produced GluR2Q homomeric AMPARs were incorporated into CA1 synapses and functioned as postsynaptic receptors (Shi et al., 2001).

In this study, we showed that GluR2Q AMPARs expressed by Sindbis viral-mediated gene transfer are also effectively sorted into thorny excrescences and function as new postsynaptic receptor channels at MF synapses. This synaptic delivery of GluR2Q occurred in the presence of tetrodotoxin or CNQX (our unpublished data). It is thus likely that the mechanism for the activityindependent synaptic delivery of GluR2Q at MF synapses is similar to that at CA1 synapses. However, it remains to be determined whether the synaptic delivery of AMPARs containing GluR1 subunits also occurs in an activity-dependent manner at MF synapses.

\section{No influence of generation of new $\mathrm{Ca}^{2+}$ pathways on MF LTP}

CA1 LTP is induced by postsynaptic $\mathrm{Ca}^{2+}$ influx via NMDARs. In contrast, MF LTP has been proposed to be induced by a presynaptic mechanism (Staubli et al., 1990; Zalutsky and Nicoll, 1990; Ito and Sugiyama, 1991; Katsuki et al., 1991; Castillo et al., 1994; Mellor and Nicoll, 2001). The difference in the mechanism for LTP induction between the two synapses could be attributable to differences in the distribution of NMDARs in the postsynaptic sites. NMDARs are distributed most abundantly at CA1 dendritic spines postsynaptic to the Schaffer collaterals, whereas NR1 and NR2A subunits are of low abundance and NR2B is almost undetectable in CA3 complex spines postsynaptic to MFs (Monaghan and Cotman, 1985; Fritschy et al., 1998; Watanabe et al., 1998). However, sufficient levels of $\mathrm{Ca}^{2+}$ ions have been shown to be supplied by $\mathrm{Ca}^{2+}$ entry through VDCCs and/or $\mathrm{Ca}^{2+}$ mobilization from internal stores during activation of MF synapses (Jaffe and Brown 1997; Yeckel et al.; 1999; Reid et al., 2001). Several reports have suggested that MF LTP is dependent on an increase in postsynaptic $\mathrm{Ca}^{2+}$ level (Williams and Johnston, 1989; Jaffe and Johnston, 1990). Later, it was proposed that NMDAR-independent MF LTP should be subdivided into two

CA3 pyramidal cells. $C$, Summary of the data from uninfected (open circles; $n=5$ ) and SIN-EG-GluR2Q-infected ( filled circles; $n=5$ ) CA3 pyramidal cells. There was no significant difference in the magnitude of LTP between uninfected and SIN-EG-GluR2Q-infected cells. $D$, Scatter plots showing no correlation between the magnitude of LTP and the RI value of MF EPSCs in uninfected (open circles) and SIN-EG-GluR2Qinfected ( filled circles) cells. 
forms: B-HFS applied to MF induced a form of LTP that was dependent on a rise in postsynaptic $\mathrm{Ca}^{2+}$, whereas L-HFS elicited MF LTP by a presynaptic mechanism (Urban and Barrionuevo, 1996). More recently, MF LTP induced by either stimulation protocol was reported to similarly require a rise in postsynaptic $\mathrm{Ca}^{2+}$ (Yeckel et al., 1999). However, it should be noted that this proposal for the involvement of postsynaptic $\mathrm{Ca}^{2+}$ in MF LTP induction was not corroborated by Mellor and Nicoll (2001), who reported that dialysis of CA3 pyramidal cells with $50 \mathrm{~mm}$ BAPTA for at least $30 \mathrm{~min}$ has no effect on MF LTP and concluded that MF LTP is induced entirely presynaptically.

In this study, we showed that the generation of new $\mathrm{Ca}^{2+}$ pathway in postsynaptic sites had no influence on MF LTP induced by either the L-HFS or B-HFS protocol. We also confirmed that this was the case under conditions in which the induction of MF LTP was not saturated with the use of a weaker tetanic stimulation. In contrast, the same manipulation elicited prominent NMDARindependent LTP at CA1 synapses (Okada et al., 2001). A straightforward interpretation of these results is that the mechanism responsible for MF LTP differs entirely from that for CA1 LTP in that MF LTP is independent of postsynaptic $\mathrm{Ca}^{2+}$.

\section{Difference in the mechanism for LTP induction between CA1 and MF synapses}

CA1 and MF synapses are very different in spine morphology, receptor composition, and $\mathrm{Ca}^{2+}$ influx and efflux mechanisms. A question arises as to the nature of the critical factors determining the differences in the postsynaptic mechanism for LTP induction between these synapses. Our results suggest that the mechanism for the induction of long-lasting increase in the postsynaptic sensitivity that responds to an increase in $\mathrm{Ca}^{2+}$ level is lacking at MF synapses.

To date, two hypotheses have been proposed for $\mathrm{Ca}^{2+}$-induced changes underlying CA1 LTP; one is an increase in the singlechannel conductance of the AMPAR caused by the activation of calcium/calmodulin-dependent protein kinase II (CaMKII), which phosphorylates Ser831 in the GluR1 subunit (Barria et al., 1997; Lee et al., 2000). The other is the activity-dependent delivery of AMPARs into the postsynaptic membranes, which is also dependent on the activation of CaMKII (Hayashi et al., 2000; Lüscher et al., 2000; Shi et al., 2001). These two hypotheses are not exclusive of each other. Hayashi et al. (2000) demonstrated that mutation of Ser831 in GluR1 to alanine (A) had no influence on the CaMKII activity-dependent delivery of this AMPAR subunit to CA1 synapses, indicating that CA1 LTP is attributable, at least partly, to the activity-dependent delivery of AMPARs into synapses.

CaMKII, the key mediator for induction of CA1 LTP, is also expressed abundantly in CA3 pyramidal cells (Ouimet et al., 1984; Erondu and Kennedy, 1985). Therefore, the difference in postsynaptic mechanism for LTP induction between CA1 and MF synapses would occur downstream of CaMKII activation. It is possible that the delivery of GluR1-containing AMPARs into MF synapses is regulated by a mechanism distinct from that into CA1 synapses. Additional studies are needed to clarify the differences in the regulatory mechanism for trafficking of GluR1containing AMPARs between CA1 and MF synapses.

\section{REFERENCES}

Amaral DG, Dent JA (1981) Development of the mossy fibers of the dentate gyrus: I. A light and electron microscopic study of the mossy fibers and their expansions. J Comp Neurol 195:51-86.

Barria A, Derkach V, Soderling T (1997) Identification of the $\mathrm{Ca}^{2+}$ / calmodulin-dependent protein kinase II regulatory phosphorylation site in the $\alpha$-amino-3-hydroxyl-5-methyl-4-isoxazole-propionate-type glutamate receptor. J Biol Chem 272:32727-32730.

Blackstad TW, Kjaerheim A (1961) Special exo-dendritic synapses in the hippocampal cortex: electron and light microscopic studies on the layer of mossy fibers. J Comp Neurol 117:133-159.

Bliss TV, Collingridge GL (1993) A synaptic model of memory: longterm potentiation in the hippocampus. Nature 361:31-39.

Brewer GJ, Torricelli JR, Evege EK, Price PJ (1993) Optimized survival of hippocampal neurons in B27-supplemented Neurobasal, a new serum-free medium combination. J Neurosci Res 35:567-576.

Burnashev N, Monyer H, Seeburg PH, Sakmann B (1992) Divalent ion permeability of AMPA receptor channels is dominated by the edited form of a single subunit. Neuron 8:189-198.

Castillo PE, Weisskopf MG, Nicoll RA (1994) The role of $\mathrm{Ca}^{2+}$ channels in hippocampal mossy fiber synaptic transmission and long-term potentiation. Neuron 12:261-269.

Chicurel ME, Harris KM (1992) Three-dimensional analysis of the structure and composition of CA3 branched dendritic spines and their synaptic relationships with mossy fiber boutons in the rat hippocampus. J Comp Neurol 325:169-182.

Chittajallu R, Alford S, Collingridge GL (1998) $\mathrm{Ca}^{2+}$ and synaptic plasticity. Cell Calcium 24:377-385.

Edwards FA, Konnerth A, Sakmann B, Takahashi T (1989) A thin slice preparation for patch clamp recordings from neurones of the mammalian central nervous system. Pflügers Arch 414:600-612.

Ehrengruber MU, Lundstrom K, Schweitzer C, Heuss C, Schlesinger S, Gähwiler BH (1999) Recombinant Semliki Forest virus and Sindbis virus efficiently infect neurons in hippocampal slice cultures. Proc Natl Acad Sci USA 96:7041-7046.

Erondu NE, Kennedy MB (1985) Regional distribution of type II $\mathrm{Ca}^{2+}$ / calmodulin-dependent protein kinase in rat brain. J Neurosci 5:3270-3277.

Feldmeyer D, Kask K, Brusa R, Kornau HC, Kolhekar R, Rozov A, Burnashev N, Jensen V, Hvalby O, Sprengel R, Seeburg PH (1999) Neurological dysfunctions in mice expressing different levels of the Q/R site-unedited AMPAR subunit GluR-B. Nat Neurosci 2:57-64.

Fritschy JM, Weinmann O, Wenzel A, Benke D (1998) Synapse-specific localization of NMDA and $\mathrm{GABA}_{\mathrm{A}}$ receptor subunits revealed by antigen-retrieval immunohistochemistry. J Comp Neurol 390:194-210.

Gwag BJ, Kim EY, Ryu BR, Won SJ, Ko HW, Oh YJ, Cho YG, Ha SJ, Sung YC (1998) A neuron-specific gene transfer by a recombinant defective Sindbis virus. Brain Res Mol Brain Res 63:53-61.

Hayashi Y, Shi SH, Esteban JA, Piccini A, Poncer JC, Malinow R (2000) Driving AMPA receptors into synapses by LTP and CaMKII: requirement for GluR1 and PDZ domain interaction. Science 287:2262-2267.

Hodgkin AL, Katz B (1949) The effect of sodium ions on the electrical activity of the giant axon of the squid. J Physiol (Lond) 108:37-77.

Hollmann M, Heinemann S (1994) Cloned glutamate receptors. Annu Rev Neurosci 17:31-108.

Iino M, Ozawa S, Tsuzuki K (1990) Permeation of calcium through excitatory amino acid receptor channels in cultured rat hippocampal neurones. J Physiol (Lond) 424:151-165.

Isa T, Iino M, Itazawa S, Ozawa S (1995) Spermine mediates inward rectification of $\mathrm{Ca}^{2+}$-permeable AMPA receptor channels. NeuroReport 6:2045-2048.

Isa T, Itazawa S, Iino M, Tsuzuki K, Ozawa S (1996) Distribution of neurones expressing inwardly rectifying and $\mathrm{Ca}^{2+}$-permeable AMPA receptors in rat hippocampal slices. J Physiol (Lond) 491:719-733.

Ito I, Sugiyama H (1991) Roles of glutamate receptors in long-term potentiation at hippocampal mossy fiber synapses. NeuroReport 2:333-336.

Jaffe D, Johnston D (1990) Induction of long-term potentiation at hippocampal mossy-fiber synapses follows a Hebbian rule. J Neurophysiol 64:948-960.

Jaffe DB, Brown TH (1997) Calcium dynamics in thorny excrescences of CA3 pyramidal neurons. J Neurophysiol 78:10-18.

Jia Z, Agopyan N, Miu P, Xiong Z, Henderson J, Gerlai R, Taverna FA, Velumian A, MacDonald J, Carlen P, Abramow-Newerly W, Roder J (1996) Enhanced LTP in mice deficient in the AMPA receptor GluR2. Neuron 17:945-956.

Kamiya H, Shinozaki H, Yamamoto C (1996) Activation of metabotropic glutamate receptor type 2/3 suppresses transmission at rat hippocampal mossy fibre synapses. J Physiol (Lond) 493:447-455.

Kapur A, Yeckel MF, Gray R, Johnston D (1998) L-Type calcium channels are required for one form of hippocampal mossy fiber LTP J Neurophysiol 79:2181-2190.

Katsuki H, Kaneko S, Tajima A, Satoh M (1991) Separate mechanisms of long-term potentiation in two input systems to CA3 pyramidal neurons of rat hippocampal slices as revealed by the whole-cell patchclamp technique. Neurosci Res 12:393-402.

Langdon RB, Johnson JW, Barrionuevo G (1995) Posttetanic potentiation and presynaptically induced long-term potentiation at the mossy fiber synapse in rat hippocampus. J Neurobiol 26:370-385.

Lee HK, Barbarosie M, Kameyama K, Bear MF, Huganir RL (2000) 
Regulation of distinct AMPA receptor phosphorylation sites during bidirectional synaptic plasticity. Nature 405:955-959.

Lüscher C, Nicoll RA, Malenka RC, Muller D (2000) Synaptic plasticity and dynamic modulation of the postsynaptic membrane. Nat Neurosci 3:545-550

Malinow R, Mainen ZF, Hayashi Y (2000) LTP mechanisms: from silence to four-lane traffic. Curr Opin Neurobiol 10:352-357.

Mellor J, Nicoll RA (2001) Hippocampal mossy fiber LTP is independent of postsynaptic calcium. Nat Neurosci 4:125-126.

Monaghan DT, Cotman CW (1985) Distribution of $N$-methyl-Daspartate-sensitive L- $\left[{ }^{3} \mathrm{H}\right]$ glutamate-binding sites in rat brain. J Neurosci 5:2909-2919.

Nicoll RA, Malenka RC (1999) Expression mechanisms underlying NMDA receptor-dependent long-term potentiation. Ann NY Acad Sci 868:515-525.

Okada T, Yamada N, Kakegawa W, Tsuzuki K, Kawamura M, Nawa H, Iino M, Ozawa S (2001) Sindbis viral-mediated expression of $\mathrm{Ca}^{2+}$. permeable AMPA receptors at hippocampal CA1 synapses and induction of NMDA receptor-independent long-term potentiation. Eur J Neurosci 13:1635-1643.

Ouimet CC, McGuinness TL, Greengard P (1984) Immunocytochemical localization of calcium/calmodulin-dependent protein kinase II in rat brain. Proc Natl Acad Sci USA 81:5604-5608.

Ozawa S, Iino M, Tsuzuki K (1991) Two types of kainate response in cultured rat hippocampal neurons. J Neurophysiol 66:2-11.

Reid CA, Fabian-Fine R, Fine A (2001) Postsynaptic calcium transients evoked by activation of individual hippocampal mossy fiber synapses. J Neurosci 21:2206-2214.

Robain O, Barbin G, Billette d, V, Jardin L, Jahchan T, Ben Ari Y (1994) Development of mossy fiber synapses in hippocampal slice culture. Brain Res Dev Brain Res 80:244-250.

Seeburg PH (1993) The TINS/TiPS Lecture. The molecular biology of mammalian glutamate receptor channels. Trends Neurosci 16:359-365.

Shi SH, Hayashi Y, Esteban JA, Malinow R (2001) Subunit-specific rules governing AMPA receptor trafficking to synapses in hippocampal pyramidal neurons. Cell 105:331-343.

Staubli U, Larson J, Lynch G (1990) Mossy fiber potentiation and longterm potentiation involve different expression mechanisms. Synapse 5:333-335.

Stoppini L, Buchs PA, Muller D (1991) A simple method for organotypic cultures of nervous tissue. J Neurosci Methods 37:173-182.

Stuart GJ, Sakmann B (1994) Active propagation of somatic action potentials into neocortical pyramidal cell dendrites. Nature 367:69-72.

Urban NN, Barrionuevo G (1996) Induction of hebbian and nonhebbian mossy fiber long-term potentiation by distinct patterns of high-frequency stimulation. J Neurosci 16:4293-4299.

Urban NN, Langdon RB, Barrionuevo G (1994) The duration and pattern of high frequency stimulation influence the time course of potentiation and the mossy fiber-CA3 synapse. Soc Neurosci Abstr 20:715.

Watanabe M, Fukaya M, Sakimura K, Manabe T, Mishina M, Inoue Y (1998) Selective scarcity of NMDA receptor channel subunits in the stratum lucidum (mossy fibre-recipient layer) of the mouse hippocampal CA3 subfield. Eur J Neurosci 10:478-487.

Wenthold RJ, Petralia RS, Blahos II J, Niedzielski AS (1996) Evidence for multiple AMPA receptor complexes in hippocampal CA1/CA2 neurons. J Neurosci 16:1982-1989.

Williams S, Johnston D (1989) Long-term potentiation of hippocampal mossy fiber synapses is blocked by postsynaptic injection of calcium chelators. Neuron 3:583-588.

Yamada KA, Tang CM (1993) Benzothiadiazides inhibit rapid glutamate receptor desensitization and enhance glutamatergic synaptic currents. J Neurosci 13:3904-3915.

Yeckel MF, Kapur A, Johnston D (1999) Multiple forms of LTP in hippocampal CA3 neurons use a common postsynaptic mechanism. Nat Neurosci 2:625-633.

Zalutsky RA, Nicoll RA (1990) Comparison of two forms of long-term potentiation in single hippocampal neurons. Science 248:1619-1624. 